\title{
Current Defence Policy and Modernisation Goals of the Croatian Armed Forces
}

\begin{abstract}
The internal and external security environment of Croatia has changed gradually since the declaration of independence in 1991. In the beginning, as in a post-war country, hard security played a vital role in the security policy documents, as reflected in the National Security Strategy (NSS) of 2002. With the accession to the North Atlantic Treaty Organisation (NATO) in 2009 and to the European Union (EU) in 2013, multilateral cooperation and collective defence had been prioritised and the new NSS from 2017 was designed to mirror this approach. The changed security environment spurred a reformed approach to defence matters and resulted in increased participation in international peace operations under EU, NATO and UN auspices. Furthermore, as a NATO member, Croatia needs to be ready to answer challenges threatening the collective security of the organisation, such as cyber threats ranging from fake news and foreign electoral intervention to cyberattacks. The first part of this analysis shows what path Croatia has taken after the declaration of independence, which is followed by introducing the current goals of Croatian security policy. Finally, international peace operations, defence spending trends and the capability development priorities of the Croatian Armed Forces are discussed.
\end{abstract}

Keywords: Croatia, NATO, defence strategy, armed forces, foreign policy, defence spending

\section{Croatia's foreign policy path taken after independence}

Soon after gaining independence in 1991, Croatian foreign policy turned toward the EU, which was expressed in rhetoric and steps towards integration as well. The rhetoric focused on Europeanisation, and the term "Balkans" was used to differentiate Croatia from the other ex-Yugoslavian countries. ${ }^{1}$ Thus, Croatian officials from the early 1990s referred to the country as Western European, Central European, European, Southeast European, Mediterranean or Danubian, but never as Balkan. ${ }^{2}$ As a further step, Croatia turned to a self-designated role of being Europe's 'ambassador' in the region, and emphasised that their contribution to security in Southeast Europe will bring this region closer to peace. ${ }^{3}$

With the accession to NATO in 2009 and to the EU in 2013, Croatia achieved its most important foreign policy goals, and by now the country is in the process of defining its new directions to become a relevant actor in Europe in general, and in Southeast Europe in particular. ${ }^{4}$ Since 2013 multilateral cooperation enjoys great significance, which is a new

1 Razsa, Maple - Lindstrom, Nicole: Balkan Is Beautiful: Balkanism in the Political Discourse of Tudman's Croatia. East European Politics and Societies: and Cultures, Vol. 18, No. 4, 2004, pp. 628-650.

2 Vaulasvirta, Mitjo: Representations of the 'Balkans' in the Foreign Policy Discourses of Croatia, Macedonia and Bosnia and Herzegovina. Contemporary Southeastern Europe, Vol. 4, No. 1, 2017, p. 32.

VAulasvirta (2017): op. cit. 35.

Knezovic, Sandro - KLepo, Nani: Croatian Foreign Policy in 3D. Hans Seidel Stiftung, Zagreb, 2017, p. 5. 
phenomenon compared to the period before. The NSS from $2002^{5}$ clearly characterised the bilateral relations of Croatia with its neighbours, but the new strategy from 2017 focuses on multilateral arenas and it states that for Croatia NATO is a guarantee of peace and security, and besides being a member of the EU, bilateral relations with the United States will be the most important pillars of Croatian foreign policy. ${ }^{6}$

\section{Croatia's objectives in the security realm}

The main goal of the Armed Forces of Croatia is to defend the territorial integrity, sovereignty and independence of Croatia. Although a military attack against Croatia is not likely, the Armed Forces are ready to deter, halt and repel armed aggression against the country, and they also contribute to the defence of allies in potential operations according to Article 5 of the Washington Treaty on collective defence. ${ }^{7}$

The second goal of the Armed Forces is the contribution to international security. This mission is achieved by participating in peace support missions, which aim to prevent human casualties and to resolve crises and conflicts. The Armed Forces participate in these operations under the auspices of international organisations with capabilities that mostly suit the operational and political needs of the respective mission. ${ }^{8}$ Besides providing troops and education, Croatia is active in defence diplomacy and arms control, disarmament and non-proliferation in accordance with international treaties. ${ }^{9}$

To live up to these challenges, the NSS from 2017 sets clear goals considering the budget and the tasks of the defence sector. The NSS describes Croatia's military capabilities as a force capable of reacting to the changing circumstances of the international environment. The Armed Forces have been developing their capabilities to defend Croatia's territory on land, at sea, in the air and in cyberspace. According to the document, the unilateral use of the Armed Forces is possible (as self-help in defensive operations), but only until the activation of collective defence. Thus, Croatia will balance between national and allied obligations and will increase its defence budget to $2 \%$ of GDP, taking into consideration its economic possibilities and national priorities. ${ }^{10}$

As the NSS 2017 states, Croatia is willing to be active in humanitarian and developmental assistance besides peace missions. ${ }^{11}$ In 2011, Croatia was removed from the Organization for Economic Cooperation and Development (OECD) list of official development assistance (ODA) recipients, and the country set the goal of investing $0.33 \%$ of its GDP in development cooperation by $2015 .{ }^{12}$ However, only $\$ 51$ million was spent on ODA in 2015 , amounting to $0.09 \%$ of its GNI; while in 2016 the sum was $\$ 41$ million, which

\footnotetext{
NSS: Strategy for the Republic of Croatia's National Security, [online], 2002, pp. 12-13. Source: The Croatian Parliament (Hrvatski Sabor) [25.09.2018.]

6 NSS: The Republic of Croatia: National Security Strategy, [online], 2017, p. 17. Source: The Croatian Parliament (Hrvatski Sabor) [25.09.2018.]

Strateski Pregled Obrane 2013, [online], 2013. Source: Ministry of Defence of the Republic of Croatia [25.09.2018.]

Ibid. 16.

Ibid. 17.

NSS: The Republic of Croatia: National... (2017), 15-16.

Ibid. 24.

12 Bosanac, Gordan: Croatian Civil Capacities for Peace Operations. Journal of Regional Security, Vol. 9, No. 2, 2014, p. 117.
} 
was equivalent to $0.07 \%$ of the GNI that year, as compared to the $0.7 \%$ U.N. target, mostly unmatched by developed countries. ${ }^{13}$

\section{Croatia in international peace support operations}

To give a framework to Croatia's participation in peace support operations, the government adopted the Strategy on Participation of Croatia in International Missions and Operations (SPCIMO) in 2014. ${ }^{14}$ The contribution of Croatia to international missions is mostly provided by members of the Armed Forces and civilian experts. On the one hand, the aim of the deployment of military personnel is to protect civilians and to assure humanitarian aid efforts. On the other hand, civil missions are creating, strengthening and maintaining social functions, such as police, judicial system, border security, customs services or the prison system in mission theatres. The priority is given to those missions, which strengthen the alliance with the U.S. and other European countries. ${ }^{15}$

Between 1999 and 2014, Croatia participated in 19 UN peacekeeping missions with 1,300 military officers in total. Recently, the most significant contribution was provided to the UN Disengagement Observer Force (UNDOF) in the Golan Heights, but in March 2013 Croatia withdrew its troops because of the risky situation in the region. ${ }^{16}$ Currently Croatia is involved in 3 UN-led missions with a total of 69 officers. Zagreb delegates 9 experts to the UN Military Observer Group in India and Pakistan (UNMOGIP), 7 experts to the UN Mission for the Referendum in Western Sahara (MINURSO) and 52 contingent troops along with 1 staff officer to the UN Interim Force in Lebanon (UNIFIL). ${ }^{17}$

Croatia's support to NATO began in 1995, when it participated in assisting IFOR and then SFOR in Bosnia and Herzegovina. Since Croatia joined NATO in 2009, it participated in several missions, such as the International Security Assistance Force (ISAF) in Afghanistan and Operation Unified Protector in Libya. ${ }^{18}$ Croatia in 2017 contributed 33 personnel to NATO's peacekeeping mission Kosovo Force (KFOR). ${ }^{19}$ KFOR supports the development of the Kosovo Security Force (KSF) through advice, training and capacity building and Croatian soldiers train themselves to participate in riot control and removing road blocks. ${ }^{20}$ The Croatian troops among others provide three helicopter crews, an aeronautical-technical maintenance team and a national support element. ${ }^{21}$ Since 2015, Zagreb participates with 95 personnel in the Resolute Support Mission (RSM) in Afghanistan, as well. RSM trains and advises Afghan security forces in a vast variety of fields from budget-

\footnotetext{
13 Development aid rises again in 2016, [online], 2017, p. 5. Source: Organization for Economic Cooperation and Development [25.09.2018.]

14 Stragegija Sudjelovanje Republike Hrvatske u Međunarodnim Misijama i Operacijama, [online], 2014. Source: Croatian Government [25.09.2018.]

15 Ibid. 4.

16 Peacekeeping Contributor Profile: Croatia, [online], 2014. Source: Providing for Peacekeeping [25.09.2018.]

17 Troop and police contributors, [online], 2018. Source: United Nations [25.09.2018.]

18 Rihtaric, Apolonija: Why Croatia urgently needs a new holistic National Security Strategy. Fokus, No. 5, 2016 , p. 2.

19 KFOR: Key Facts and Figures, [online], 2017. Source: NATO [25.09.2018.]

20 U misiji KFOR - HRZ u punom pogonu, [online], 2017. Source: Obris [25.09.2018.]

${ }^{21}$ HRZ u multinacionalnoj vjezbi KFOR-a na Kosovu, [online], 2016. Source: Obris [25.09.2018.]
} 
ing through force generation to intelligence activities. ${ }^{22}$ In most of these missions they do not play a leading role, except for the RSM in Afghanistan, where under the framework of the U.S. - Adriatic Charter, A-5 - Croatia is the lead nation among its Southeast European partners. Following the initiative of Croatia, ${ }^{23}$ Albania, Bosnia and Herzegovina, Croatia, Macedonia and Montenegro participate jointly under Croatian command in the RSM. ${ }^{24}$

Besides post-conflict stabilisation missions, Croatia participates in NATO's strengthened deterrence and defence posture with military presence in Poland and Lithuania. In Poland, Croatia falls under the command of the U.S., and in Lithuania under that of Germany. The first Croatian contingent sent to Poland included 90 members of the Artillery Regiment of the Armed Forces along with logistical support, staff personnel, associated weapons, equipment and vehicles. ${ }^{25}$ The contingent deployed in Lithuania comprised of 181 soldiers and their equipment, including 13 armoured vehicles, one armoured ambulance vehicle, four trucks, one off-road truck and a field combat vehicle. ${ }^{26}$

The first EU CSDP mission that Croatia joined was the EU Police Mission (EUPOL) in Afghanistan in 2002, and later they also contributed to the EU Rule of Law Mission in Kosovo (EULEX), the EU Monitoring Mission in Georgia (EUMM Georgia) and the EU Coordinating Office for Palestinian Police Support (EU COPPS) ${ }^{27}$ Expressing its commitment towards a shared Mediterranean identity, Croatia participates in the EU Naval Force ATALANTA (EU NAVFOR) mission in Somalia, and in the EU Naval Force Mediterranean Operation Sophia (EU NAVFOR MED) ${ }^{28}$ Zagreb currently supports the Somalian EU NAVFOR Mission with 25 personnel of the Armed Forces, ${ }^{29}$ and the EU NAVFOR MED with up to 3 personnel in the period of $2017-2018 .{ }^{30}$ In the ATALANTA mission Croatian forces were responsible for the safety of the World Food Programme Vessel MSM Douro until 2017, but there is no clear available information about the exact duties of the current deployment. ${ }^{31}$

As it can be seen, Croatia is active in contributing to international peacekeeping operations, with a focus on NATO and the EU, while UN missions also play an important role. The impact of the comprehensive NSS is clear if we take a look at the decisions on deployments. The Mediterranean identity is reflected in Croatia's involvement in the EU NAVFOR and EU NAVFOR MED missions, and its engagement in Southeast Europe is well represented by the KFOR contribution. The participation of Croatian forces in the

\footnotetext{
22 Resolute Support Mission (RSM): Key Facts and Figures, [online], 2017. Source: NATO RSM [25.09.2018.]

Sveobuhvatni Regionalni Sastanak Ministara Obrane, [online], 22.10.2015. Source: Hrvatski Vojnik [25.09.2018.]

24 President Grabar-Kitarovic Visits Croatian Soldiers in Afghanistan, [online], 20.05.2016. Source: Total Croatia News [25.09.2018.]

25 Croatian Soldiers Leave for NATO Mission in Poland, [online], 12.10.2017. Source: Total Croatia News [25.09.2018.]

26 Croatian Army Departs for NATO Mission in Lithuania, [online], 26.11.2017. Source: Total Croatia News [25.09.2018.]

27 Rihtaric (2016): op. cit. 2.

28 EUNAVFOR Med Factsheet, [online], 2018. Source: EUNAVFOR [25.09.2018.]

29 Video-Sabor Grmoja: 'Ovo vam je zadnji put, nećete me tako vrijeđati!', Jandroković: 'Vi meni prijetite, ne bojim vas se', [online], 23.11.2017. Source: Direktno.hr [25.09.2018.]; Sabor prihvatio Zakon o pravima hrvatskih branitelja: Njihova prava i povlastice koštat će 219.2 milijuna kuna, [online], 30.11.2017. Source: Net [25.09.2018.]

30 Government adopts draft decisions on participation of CAF in NATO/EU operations, [online], 2017. Source: Ministry of Defence of the Republic of Croatia [25.09.2018.]

31 Croatian Maritime Protection Team Awarded EU Operation Atalanta Medal for Keeping WFP Vessel MSM Douro Safe from Pirates off Coast of Somalia, [online], 2017. Source: EU NAVFOR ATALANTA Somalia [25.09.2018.]
} 
strengthened forward presence of NATO in Poland and Lithuania is an expression of commitment towards the collective structures, which are determining elements of the NSS adopted in 2017.

On the political spectrum, there are no significant disagreements among the parties about the role of Croatia in international operations. Likewise, in the military the recruitment occurs without problems and the wider population in general shows unconcern towards peacekeeping operations. Croatia usually does not play a leading role in missions, but its forces are rather integrated within already framed operations in the respective mission theatres. For these reasons, the agenda of political parties in not questioned in this regard, because there are no significant potential gains of bringing up the operations in the public debate. $^{32}$

\section{Croatian Armed Forces and its development}

The level of defence spending in Croatia has been low since the 2000s and decreased again after the 2008 financial crisis. The operational spectrum of the Armed Forces is mainly defensive, with a special focus paid to the international obligations stemming from NATO's collective defence and peace support operations. Although the defence spending is low, there are some developments in defence capabilities, especially when it comes to the air force where the acquisition of equipment is underway. However, when it comes to the land forces and the navy, there are no significant investments in the foreseeable future.

\section{Defence spending trends}

The level of defence spending in Croatia has been relatively low compared to neighbours in the past decade. The peak period of Croatian defence expenditures was the middle of the 1990s, but the stable security environment let Croatia decrease spending on defence matters. Since then, no specific events but only NATO's requirements have spurred Croatia to strengthen military capabilities. ${ }^{33}$ As a first step in this direction the Croatian Armed Forces Long-Term Development Plan 2015-2024 (LTDP 2015-2024) agreed not to reduce defence spending further, beyond its current level, which was $1.41 \%$ of GDP in $2014 .^{34}$

Anticipating future spending, the plan drafted in 2014 aims to increase defence expenditures only with the recovery of the economy and GDP growth. If we look at the numbers provided by NATO, the Croatian defence expenditures have not begun increasing yet, and reached an all-time low level in 2016. The military spending in 2010 was $1.54 \%$ of GDP, and in 2011 it peaked at $1.6 \%$ of GDP; however, since 2012 the numbers are constantly decreasing, and the last published data was 1.24\% of GDP in $2016 .{ }^{35}$ This trend fits into the regional dynamics, as can be seen in Table 1, because neither Slovenia and Montenegro,

\footnotetext{
Peacekeeping Contributor Profile... (2014).

BMI: Croatia Defence and Security Report 2016. BMI Industry Report and Forecasts Series, January 2017, p. 10.

4 The Croatian Armed Forces Long-Term Development Plan 2015-2024, [online], 2014, p. 94. Source: Official Gazette, No. 151 [25.09.2018.]

35 Defence Expenditure of NATO Countries (2010-2017), [online], 2017, p. 8. Source: NATO [25.09.2018.]
} 
nor Albania and Hungary could reach a higher defence expenditure levels in relation to GDP since 2010.

Table 1: Defence expenditures as a share of GDP (\%) based on 2010 exchange rates

\begin{tabular}{|l|c|c|c|c|c|c|c|}
\hline & $\mathbf{2 0 1 0}$ & $\mathbf{2 0 1 1}$ & $\mathbf{2 0 1 2}$ & $\mathbf{2 0 1 3}$ & $\mathbf{2 0 1 4}$ & $\mathbf{2 0 1 5}$ & $\mathbf{2 0 1 6}$ \\
\hline Albania & 1.56 & 1.53 & 1.49 & 1.41 & 1.35 & 1.16 & 1.10 \\
\hline Croatia & 1.24 & 1.60 & 1.53 & 1.47 & 1.41 & 1.37 & 1.24 \\
\hline Hungary & 1.04 & 1.05 & 1.04 & 0.95 & 0.87 & 0.93 & 1.04 \\
\hline Montenegro & 1.80 & 1.75 & 1.66 & 1.47 & 1.50 & 1.42 & 1.49 \\
\hline Slovenia & 1.61 & 1.30 & 1.17 & 1.06 & 0.98 & 0.94 & 1.02 \\
\hline
\end{tabular}

Source: Defence Expenditure of NATO Countries (2010-2017), [online], 2017, p. 8. Source: NATO [25.09.2018.]

\section{Operational spectrum}

The Croatian Armed Forces must be ready to answer security threats and challenges targeting Croatia. This responsibility requires the Armed Forces to have capabilities for the following tasks:

- to defend Croatia and its allies according to Article 5 of the Washington Treaty

- to participate in crisis response operations abroad, which contribute to international security and stability

- and to assist civilian institutions and population to carry out humanitarian operations at home and abroad ${ }^{36}$

The Armed Forces between 2015 and 2024 will continue to focus on international cooperation, which is manifested in participation in NATO and EU missions. To intensify this contribution, Smart Defence and Pooling and Sharing initiatives are to be improved, and a special emphasis is given to developing search and rescue, medical transportation and border control capabilities. ${ }^{37}$ The Croatian LTDP 2015-2024 contains exact data about the number of troops needed to fulfil the mentioned responsibilities. The Armed Forces develop an initial response force with up to 20,000 members, who will be assigned to the Reserve Armed Forces with weapons and equipment. The Armed Forces ensure the growth of the troop numbers to the level needed to deter possible armed aggression through reintroducing compulsory military service from 2019. Apart from them, 1,000 troops are to be trained to participate in operations abroad. With these numbers Croatia will contribute $1 \%$ of the NATO Immediate Response Forces. ${ }^{38}$

The Croatian Armed Forces have troops to operate on land, sea and in the air with mainly defensive capabilities. By the end of 2018, the land forces will be able to send a combat group-sized mechanised battalion to missions abroad. To reach this goal, $50 \%$ of the

\footnotetext{
36 The Croatian Armed Forces... (2014), 13.

37 Ibid.

38 Ibid. 16.
} 
troops are trained to be capable of participating in peace support operations. The naval forces of Croatia focus on the Adriatic and the protection of the rights and interests of the country, while they continue to develop capabilities for NATO and EU operations as well. From 2018 on the air force will have eight medium transport helicopters available for peace support operations, and $40 \%$ of the air force will be trained for participating in missions. ${ }^{39}$

\section{Capability development priorities}

Since the accession to NATO in 2009, the Croatian Armed Forces have been on a modernisation path. However, the impacts of the financial crisis impeded Croatia to increase its defence budget and prevented the implementation of modernization programs. Hence, their equipment remained outdated and in need of replacement, especially those of the navy and the air force. Nevertheless, since 2014 the country has taken steps to equip its military with up-to-date weaponry, mainly relying on the U.S. as a key partner in providing training, equipment and funding. ${ }^{40}$

The LTDP 2015-2024 outlines the aims of capability development of the Croatian army. The long-term goals of the development are optimising the strength and structure of the forces, developing consistent cooperation within CSDP and UN missions, designing the Armed Forces based on competencies and social accountability, and most importantly, strengthening the capabilities to implement non-military tasks both at home and abroad. These include assistance to civil institutions and population, as well as search and rescue operations on land, at sea and in the air. ${ }^{41}$

Most of the goals set by the capability development strategy preceding 2015 were not achieved. To fulfil these goals, Zagreb needs to invest in its defence capabilities. To complement these deficiencies, one of the most important development priorities is the modernisation of the air force. ${ }^{42}$ To proceed, the U.S. donated 16 Bell OH-58D Kiowa Warrior helicopters to Croatia in 2016, to which the government approved the purchase of AGM-114 Hellfire missiles in 2017. The delivery of the missiles is due in 2020, which will cost USD 3.2 million. ${ }^{43} \mathrm{OH} 58 \mathrm{D}$ Kiowa is a single-engine, single rotor helicopter used for observation, utility and fire support in operations. ${ }^{44}$ There is another plan to receive a squadron of new transport helicopters by 2025, when the currently operating Mi- 8 helicopters' service time expires. The equipment replacing the Mi-8s would be Sikorsky UH-60A Black Hawk, manufactured between 1977 and 1989 and upgraded since then. The upgraded model has larger rotor blades, digital avionics, glass cockpit and an advanced computer flying system. ${ }^{45}$

Apart from the helicopters, Croatia's fighter jets, currently MiG-21s, are in need of replacement; this was also part of the 2006-2015 strategy but was not realised. According

\footnotetext{
Ibid. 17.

40 BMI (2017), 20.

41 The Croatian Armed Forces... (2014), 15.

BMI (2017), 17.

3 Croatia to arm OH-58D helicopters with Hellfire missiles, [online], 2017. Source: Jane's 360 [25.04.2018.]

4 BMI (2017), 20.

45 Croatia Buying US Black Hawk Helicopters, [online], 09.04.2018. Source: Total Croatia News [25.09.2018.]
} 
to the current strategy, the MiG-21s remain in service until $2024,{ }^{46}$ while replacement begins in 2019. ${ }^{47}$ On 27 March 2018, the Croatian Defence Council made the decision that 12 used F-16D 'Barak' fighter jets from Israel will be bought for USD 500 million. These will replace the MiG-21s, and they will be delivered to Croatia until 2020. ${ }^{48}$ Although not all of the new equipment will be new, which is a target of public criticism, with the delivery of these, the reliance on Russian technology will be eliminated.

Regarding the land forces, the focus of the LTDP 2015-2024 is on improving quality and not quantity; therefore, the number of personnel is continuously decreasing. In 2008 the number was 22,000 , in $201319,600^{49}$ and in 2018 it was 18,525 active military personnel. ${ }^{50}$ Nevertheless, reacting to threats on the ground in the region, such as the Russian military actions in Ukraine, the increased migration flows and the country's vulnerable geopolitical location, the land forces will undergo modernisation. Thus, the main Croatian Tank Company will be modernised to procure up-to-date technology and the combat vehicles in service will be upgraded with mobile anti-armour systems, communication systems and artillery. Air defence systems, as well as demining capabilities will be improved. ${ }^{51}$

As Croatia has a long coastline, the Croatian Navy has implemented projects related to developing its maritime capabilities. However, most of these developments were restricted to the coast guards' operational capacity and the navy's radar capabilities. One of the new elements will be the consolidation of maritime surveillance sensor data so that it is well integrated with NATO's own surveillance capabilities. Secondly, Croatia needs to procure more coastal patrol boats from abroad because it lacks the domestic manufacturing base. And thirdly, Croatia needs to develop its own naval training facilities and maintenance harbours. ${ }^{52}$

\section{Conclusions}

Since the declaration of independence, Croatian security and defence policy changed gradually. The focus on bilateral relations and threats has been replaced by multilateral cooperation and the development of response capabilities in case of the activation of collective defence. As a result, the Croatian Armed Forces actively participate in international peace operations, as well as in NATO's strengthened deterrence and defence posture in Poland and Lithuania.

The focus on multilateral cooperation and collective defence requires the Armed Forces to increase the defence budget to $2 \%$ of GDP and to modernise their capabilities. Thus, in line with the plans outlined, the air force goes through an intense modernisation of equipment, while the land forces and the navy are also planned to be modernised in line with the current tasks and challenges. Since the LTDP sets modernisation goals until 2024,

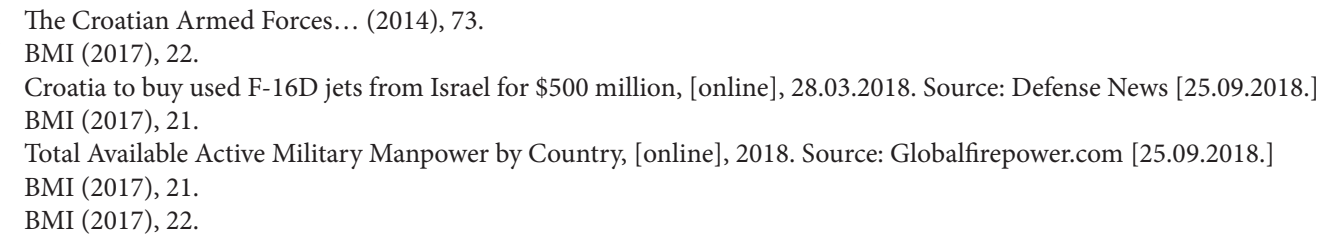


gradual changes are expected in this direction in the next years, while the continuous modernisation of the armed forces depends on realising the planned defence budget increase.

\section{REFERENCES}

BMI: Croatia Defence and Security Report 2016. BMI Industry Report and Forecasts Series, January 2017.

Bosanac, Gordan: Croatian Civil Capacities for Peace Operations. Journal of Regional Security, Vol. 9, No. 2, 2014, pp. 93-109. DOI: https://doi.org/10.11643/issn.2217-995x142ppb45

Croatian Army Departs for NATO Mission in Lithuania, [online], 26.11.2017. Source: Total Croatia News [25.09.2018.]

Croatia Buying US Black Hawk Helicopters, [online], 09.04.2018. Source: Total Croatia News [25.09.2018.]

Croatia to arm OH-58D helicopters with Hellfire missiles, [online], 2017. Source: Jane's 360 [25.04.2018.]

Croatia to buy used F-16D jets from Israel for $\$ 500$ million, [online], 28.03.2018. Source: Defense News [25.09.2018.]

Croatian Maritime Protection Team Awarded EU Operation Atalanta Medal for Keeping WFP Vessel MSM Douro Safe from Pirates off Coast of Somalia, [online], 2017. Source: EU NAVFOR ATALANTA Somalia [25.09.2018.]

Croatian Soldiers Leave for NATO Mission in Poland, [online], 12.10.2017. Source: Total Croatia News [25.09.2018.]

Defence Expenditure of NATO Countries (2010-2017), [online], 2017. Source: NATO [25.09.2018.]

Development aid rises again in 2016, [online], 2017. Source: Organization for Economic Cooperation and Development [25.09.2018.]

EUNAVFOR Med Factsheet, [online], 2018. Source: EUNAVFOR [25.09.2018.]

Government adopts draft decisions on participation of CAF in NATO/EU operations, [online], 2017. Source: Ministry of Defence of the Republic of Croatia [25.09.2018.]

HRZ u multinacionalnoj vjezbi KFOR-a na Kosovu, [online], 2016. Source: Obris [25.09.2018.]

Sveobuhvatni Regionalni Sastanak Ministara Obrane, [online], 22.10.2015. Source: Hrvatski Vojnik [25.09.2018.]

KFOR: Key Facts and Figures, [online], 2017. Source: NATO [25.09.2018.]

Knezovic, Sandro - KLePo, Nani: Croatian Foreign Policy in 3D. Hans Seidel Stiftung, Zagreb, 2017.

NSS: Strategy for the Republic of Croatia's National Security, [online], 2002. Source: The Croatian Parliament (Hrvatski Sabor) [25.09.2018.]

NSS: The Republic of Croatia: National Security Strategy, [online], 2017. Source: The Croatian Parliament (Hrvatski Sabor) [25.09.2018.]

Peacekeeping Contributor Profile: Croatia, [online], 2014. Source: Providing for Peacekeeping [25.09.2018.]

President Grabar-Kitarovic Visits Croatian Soldiers in Afghanistan, [online], 20.05.2016. Source: Total Croatia News [25.09.2018.]

Razsa, Maple - Lindstrom, Nicole: Balkan Is Beautiful: Balkanism in the Political Discourse of Tudman's Croatia. East European Politics and Societies: and Cultures, Vol. 18, No. 4, 2004, pp. 628-650. DOI: https:// doi.org/10.1177/0888325404266939

Resolute Support Mission (RSM): Key Facts and Figures, [online], 2017. Source: NATO RSM [25.09.2018.]

Rintaric, Apolonija: Why Croatia urgently needs a new holistic National Security Strategy. Fokus, No. 5, 2016.

Sabor prihvatio Zakon o pravima hrvatskih branitelja: Njihova prava i povlastice koštat će 219.2 milijuna kuna, [online], 30.11.2017. Source: Net [25.09.2018.]

Stragegija Sudjelovanje Republike Hrvatske u Međunarodnim Misijama i Operacijama, [online], 2014. Source: Croatian Government [25.09.2018.]

Strateski Pregled Obrane 2013, [online], 2013. Source: Ministry of Defence of the Republic of Croatia [25.09.2018.] The Croatian Armed Forces Long-Term Development Plan 2015-2024, [online], 2014. Source: Official Gazette, No. 151 [25.09.2018.]

Total Available Active Military Manpower by Country, [online], 2018. Source: Globalfirepower.com [25.09.2018.]

Troop and police contributors, [online], 2018. Source: United Nations [25.09.2018.]

U misiji KFOR - HRZ u punom pogonu, [online], 2017. Source: Obris [25.09.2018.] 
Vaulasvirta, Mitjo: Representations of the 'Balkans' in the Foreign Policy Discourses of Croatia, Macedonia and Bosnia and Herzegovina. Contemporary Southeastern Europe, Vol. 4, No. 1, 2017, pp. 26-53.

Video-Sabor Grmoja: 'Ovo vam je zadnji put, nećete me tako vrijeđati!', Jandroković: 'Vi meni prijetite, ne bojim vas se', [online], 23.11.2017. Source: Direktno.hr [25.09.2018.] 